\title{
Growth and dry matter of pitombeira seedlings under salinity levels and application of biofertilizer
}

\author{
Mário Leno Martins Véras ${ }^{1 *}$, José Sebastião de Melo Filho ${ }^{2}$, \\ Lunara de Sousa Alves ${ }^{3}$, Toni Halan da Silva Irineu ${ }^{4}$, Thiago Jardelino Dias ${ }^{2}$
}

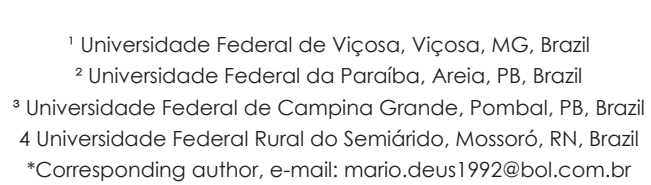

\begin{abstract}
Pitombeira is a native fruit tree from Amazon and is exploited in an extractive way. Currently, there is no commercial cultivation of this crop since there are no technologies for cultivation, propagation methods, fertilization and irrigation. In this context, the aim of this study was to evaluate growth and dry matter of pitombeira seedlings (Talisia esculenta (A. St.-Hill.) Radlk.) under salinity levels with or without bovine biofertilizer. The experiment was performed in a nursery at the State University of Paraíba (UEPB), Campus IV, in Catolé do Rocha, Paraíba, from September to December 2015. It was adopted a completely randomized design (CRD) with 10 treatments and 4 repetitions, in factorial arrangement $5 \times 2$, corresponding to 5 salinity levels: $\left(0,8 ; 2 ; 4 ; 6\right.$ e $\left.8 \mathrm{dS} \mathrm{m}^{-1}\right)$ with or without bovine biofertilization. Plant height, stem diameter, number of leaves, leaf area, total leaf area, Dickson quality index, dry mass of root, stem, leaf and the whole plant were analyzed. The increase in salinity provides a decrease in growth and dry matter of pitombeira seedlings. The use of biofertilizers mitigates the harmful effects of salinity on pitombeira seedlings.
\end{abstract}

Keywords: organic agriculture, saline water, Talisia esculenta (A. St.-Hill.) Radlk

\section{Introduction}

Pitombeira (Talisia esculenta (A. St.-Hill.)

Radlk.) is a fruit tree from the Amazon region and belongs to Sapindaceae family. Its fruits are very consumed in the Brazilian northeast region where it is cultivated in small orchards or in an extractive way. One of the obstacles in cultivating this fruit is the lack of planting techniques (Alves et al., 2013).

The use of saline water in irrigation has been considered a problem in agricultural production due to the excess of salts in the root zone, which may lead to a decrease in crop growth and yield. Another problem is the reduction in the efficiency of water use as well as the decrease in nutrients extraction by the crops (Lacerda, 2005).

Besides water shortage, the water quality is a factor that should be verified, especially in semi-arid areas. The concentration of soluble salts or salinity is important to evaluate water quality for irrigation since it is a factor that limits growth and development of crops (Bezerra et al., 2010).

The use of liquid organic fertilizers in agriculture has grown in recent years due to several factors: high cost of chemical fertilizers, conservation of natural resources, practice of agroecology, improved quality of harvested products, reduction of soil, water, plant, man and all living organisms contamination (Araújo et 
al., 2007, Alves et al., 2009).

It has been suggested the application of substances that attenuate the deleterious effect of salts to plants, reducing salt intensity and allowing the use of salt water during seedlings phase and plant growing (Cavalcante et al., 2005).

Sousa et al. (2008), Nunes et al. (2009) and Cavalcante et al. (2010) observed that bovine biofertilizer has a mitigating action on the salinity of irrigation water in yellow passion fruit (Passiflora edulis), noni (Morinda citrifolia) and guava cv. Puma (Psidium guajava).

Due to the lack of studies related to the production of pitombeira seedlings, the aim of this study was to evaluate the growth and dry matter of pitombeira seedlings (Talisia esculenta (A. St.-Hill.) Radlk.) under salinity levels with and without bovine biofertilizer.

\section{Materials and Methods}

The experiment was performed from September to December 2015 at the nursery sector of the Center for Human and Agrarian Sciences of the State University of Paraíba (UEPB) in Catolé do Rocha-PB, at $6^{\circ} 20^{\prime} 38$ " $\mathrm{S} ; 37^{\circ} 44^{\prime} 48^{\prime \prime W}$ and 275 meters of altitude. According to Koppen classification, the climate of the municipality is BSW', which is hot and dry (steppe type), with average monthly temperature above $18^{\circ} \mathrm{C}$ throughout the year.

The experiment was carried out in a completely randomized design (CRD), with a $5 \times 2$ factorial scheme, with four replicates, corresponding to five levels of electrical conductivity of irrigation water (CEW): $(0.8 ; 2 ; 4 ; 6$ and $8 \mathrm{dS} \mathrm{m}^{-1}$ ) with and without bovine biofertilizer. The experimental units were composed of five seedlings cultivated in polyethylene bags $(2 \mathrm{~kg}$ capacity).

Water analysis was performed by the Laboratory of Irrigation and Salinity (LIS) of the Center of Technology and Natural Resources of the Federal University of Campina Grande - UFCG and presented the following chemical characteristics: electrical conductivity of 0.8 $\mathrm{dS} / \mathrm{m} ; \mathrm{pH}=7.53 ; \mathrm{Ca}=2.30 \mathrm{cmol}_{\mathrm{c}} \mathrm{dm}^{-3} ; \mathrm{Mg}=1.56$ $\mathrm{cmol}_{\mathrm{c}} \mathrm{dm}^{-3} ; \mathrm{Na}=4.00 \mathrm{cmol}_{\mathrm{c}} \mathrm{dm}^{-3} ; \mathrm{K}=0.02 \mathrm{cmol}_{\mathrm{c}}$ $\mathrm{dm}^{-3} ;$ Chloride $=3.90 \mathrm{cmol}_{\mathrm{c}} \mathrm{dm}^{-3} ;$ Carbonate $=0.57$ $\mathrm{cmol}_{\mathrm{c}} \mathrm{dm}^{-3} ;$ Bicarbonate $=3.85 \mathrm{cmol}_{\mathrm{c}} \mathrm{dm}^{-3} ;$ RAS $=2.88\left(\mathrm{mmol}_{\mathrm{C}} \mathrm{H}^{-1}\right)^{1 / 2}$ and Richards Classification (1954) with $\mathrm{C}_{3} \mathrm{~S}_{1}$.

The soil used to fill the polyethylene bags was classified as Fluvic Neosol with a sandy loam texture. Samples from 0 to $20 \mathrm{~cm}$ layer were collected in a native area located at the UEPB campus. A subsample was taken to be chemically analyzed and presented the following characteristics: $\mathrm{Ca}=4.63 \mathrm{cmol}_{\mathrm{c}} \mathrm{dm}^{-3} ; \mathrm{Mg}=2.39$ $\mathrm{cmol}_{\mathrm{c}} \mathrm{dm}^{-3} ; \mathrm{Na}=0.30 \mathrm{cmol}_{\mathrm{c}} \mathrm{dm}^{-3} ; \mathrm{K}=0.76 \mathrm{cmol}_{\mathrm{c}}$ $\mathrm{dm}^{-3} ;$ Sum of bases $-\mathrm{SB}=8.08 \mathrm{cmol}_{\mathrm{c}} \mathrm{dm}^{-3} ; \mathrm{H}=0.00$ $\mathrm{cmol}_{\mathrm{C}} \mathrm{dm}^{-3} ; \mathrm{Al}=0.00 \mathrm{cmol}_{\mathrm{C}} \mathrm{dm}^{-3} ; \mathrm{CEC}=8.08$ and organic matter $=1.88 \%$.

The substrate was composed of soil and earthworm humus in a ratio of 1: 1. The worm humus analysis was performed and presented the characteristics shown in Table 1.

Table 1. Physicochemical attributes of earthworm humus and bovine biofertilizer used in the experiment. Catolé do Rocha-PB, UEPB, 2014.

\begin{tabular}{|c|c|c|c|}
\hline Earthworm humus & Values & Bovine biofertilizer & Values \\
\hline $\mathrm{pH} \mathrm{H}_{2} \mathrm{O}(1: 2.5)$ & 7.38 & $\mathrm{pH} \mathrm{H}_{2} \mathrm{O}(1: 2,5)$ & 4.68 \\
\hline Eletric Conductivity ( $\left.\mathrm{dS} \mathrm{m}^{-1}\right)$ & 2.11 & Eletric Conductivity $\left(\mathrm{dS} \mathrm{m}^{-1}\right)$ & 4.70 \\
\hline Calcium $\left(\mathrm{cmol}_{\mathrm{C}} \mathrm{dm}^{-3}\right)$ & 3.54 & Calcium $\left(\mathrm{cmol}_{\mathrm{c}} \mathrm{dm}^{-3}\right)$ & 3.75 \\
\hline Magnesium $\left(\mathrm{cmol}_{\mathrm{C}} \mathrm{dm}^{-3}\right)$ & 1.93 & Magnesium $\left(\mathrm{cmol}_{\mathrm{c}} \mathrm{dm}^{-3}\right)$ & 3.30 \\
\hline Sodium $\left(\mathrm{cmol}_{\mathrm{c}} \mathrm{dm}^{-3}\right)$ & 0.18 & Sodium $\left(\mathrm{cmol}_{\mathrm{c}} \mathrm{dm}^{-3}\right)$ & 1.14 \\
\hline Potassium $\left(\mathrm{cmol}_{\mathrm{c}} \mathrm{dm}^{-3}\right)$ & 0.14 & Potassium $\left(\mathrm{cmol}_{\mathrm{c}} \mathrm{dm}^{-3}\right)$ & 0.71 \\
\hline$S\left(\mathrm{cmol}_{\mathrm{c}} \mathrm{dm}^{-3}\right)$ & 5.79 & $\mathrm{~S}\left(\mathrm{cmol}_{\mathrm{c}} \mathrm{dm}^{-3}\right)$ & 14.45 \\
\hline Hidrogen $\left(\mathrm{cmol}_{\mathrm{c}} \mathrm{dm}^{-3}\right)$ & 0.00 & Hidrogen $\left(\mathrm{cmol}_{\mathrm{c}} \mathrm{dm}^{-3}\right)$ & 1.00 \\
\hline Aluminum $\left(\mathrm{cmol}_{\mathrm{c}} \mathrm{dm}^{-3}\right)$ & 0.00 & Aluminum $\left(\mathrm{cmol}_{\mathrm{c}} \mathrm{dm}^{-3}\right)$ & 0.00 \\
\hline Assimilable phosphorus $\left(\mathrm{cmol}_{c} \mathrm{dm}^{-3}\right)$ & 5.51 & Assimilable phosphorus $\left(\mathrm{cmol}_{\mathrm{c}} \mathrm{dm}^{-3}\right)$ & 14.45 \\
\hline
\end{tabular}


The biofertilizer was obtained by anaerobic fermentation, in other words, in a hermetically sealed environment. To release methane gas at the top of each biodigester, one end of a thin hose was coupled and the other end was immersed in a container with water. For the biofertilizer preparation, $70 \mathrm{~kg}$ of bovine manure from lactating cows and 120 liters of water were used, adding $5 \mathrm{~kg}$ of sugar and 5 liters of milk to accelerate bacteria metabolism.

Treatments with biofertilizer were applied 15 days after sowing (DAS), with intervals of 8 days, totalizing 6 applications with $10 \%$ of the total volume. Treatments with salinity levels were applied 15 days after emergence.

Before the application, biofertilizer was subjected to screen filtration to reduce the risk of watering can obstruction. Biofertilizer was analyzed and presented the following physicochemical characteristics (Table 1):

The different levels of water salinity (ECW) were obtained by the addition of sodium chloride ( $\mathrm{NaCl}$ ) to the water from the local supply system, according to Rhoades et al. (2000) and the quantity of salts $(Q)$ was determined by the equation:

$$
Q\left(m g / L^{-1}\right)=E C W \times 640 \quad \text { eq. } 1
$$

In which, ECW (dS $\mathrm{m}^{-1}$ ) represents the desired value of water electrical conductivity. The water chosen as control - S1 (0.8 dS $\mathrm{m}^{-1}$ ) comes from an Amazon well located at the UEPB.

Sowing was carried out in plastic bags $(20 \times 30 \mathrm{~cm})$ of $2 \mathrm{~kg}$ capacity. Soil was sieved and mixed with earthworm humus in a ratio of 1:1. Three pitombeira seeds were sowed in each polyethylene bag. Fourteen days after sowing, seedlings thinning was performed, keeping only the most vigorous seedling.

Sixty days after sowing (DAS), the following variables were collected and evaluated: plant height (using a measuring tape at the distance between the base and the apex of the plant, the insertion of the youngest leaf), stem diameter (was performed with a digital caliper $2 \mathrm{~cm}$ above the plant base), leaf number (obtained by counting), leaf area (obtained by measuring leaf width and length), total leaf area (was obtained by multiplying the leaf area by the number of leaves).

Dry mass of root, stem and leaf were determined after fresh matter remained in circulation oven for approximately 48 hours at 60 ${ }^{\circ} \mathrm{C}$ until a constant weight. Dry mass of the whole plant was obtained by the sum of the dried plant masses (root, stem and leaf).

Dickson quality index (Dickson et al., 1960) was obtained by the formula:

$$
\begin{aligned}
& D Q I=\underline{\text { total dry matter }} \quad \text { eq. } 2 \\
& R H D+\text { RSPR }
\end{aligned}
$$

In which: $\mathrm{RHD}=$ height/diameter ratio ; RSPR $=$ root/shoot part ratio.

Data were submitted to variance analysis by the "F" test, while the means for the application of biofertilizer were compared by Tukey's test at $5 \%$ of probability and the ones referring to water salinity levels were compared by regression analysis with the Statistical software SISVAR 5.0. (Ferreira, 2007).

\section{Results e Discussion}

According to the analysis of variance (Table 2), salinity levels statistically influenced all variables, except for plant height and stem diameter. Regarding biofertilizer, significant effects were observed only for leaf area and total leaf area. In the interaction between salinity levels and biofertilizer, there was a significant effect in all variables, except for plant height and stem diameter.

Seedlings irrigated with low salinity water showed an increase in number of leaves when compared to those irrigated with high salinity water, even without the application of bovine biofertilizer (Figure 1A). It was verified that with low salinity conditions, the seedlings obtained a maximum number of leaves (17.5 units) when irrigated with water of $0.8 \mathrm{dS} \mathrm{m}^{-1}$ under application of biofertilizer. Under high salinity water 18 dS $\mathrm{m}^{-1}$ ), the maximum number of leaves was 6.75 units and it was obtained with the application of biofertilizer. 
Table 2: Summary of analyzes of variance for plant height (PH), stem diameter (SD), number of leaves (NL), leaf area (LA), total leaf area (TLA) and Dickson Quality Index (DQI) of pitombeira seedlings (Talisia esculenta (A. St.-Hil.) Radlk.) under levels of electrical conductivity with or without bovine biofertilizer.

\begin{tabular}{|c|c|c|c|c|c|c|c|}
\hline Source of variation & DF & & & Mean & Square & & \\
\hline & & $\mathrm{PH}$ & SD & LN & LA & TLA & DQI \\
\hline & & $\mathrm{cm}$ & $\mathrm{mm}$ & Unit & $\mathrm{cm}$ plant & $\mathrm{cm}$ plant & \\
\hline Salinity levels & 4 & 25,90 ns & $0,11^{\mathrm{ns}}$ & $86,65^{* *}$ & $238,78^{* *}$ & $12218,76^{* *}$ & 1,01 ** \\
\hline Linear Regression & 1 & 15,31 ns & 0,42 ns & $137,81 * *$ & $696,14^{* *}$ & $289819,66^{* *}$ & $1,97 * *$ \\
\hline Quadratic Regression & 1 & 25,08 ns & 0,00 ns & $0,43^{\text {ns }}$ & $3,51^{\text {ns }}$ & $12948,10^{*}$ & $1,43^{* *}$ \\
\hline Regression deviation & 2 & 31,61 & 0,02 & 104,17 & 127,73 & 92985,62 & 0,31 \\
\hline Biofertilizer & 1 & $1,44^{\mathrm{ns}}$ & 0,01 ns & 4,90 ns & $135,97^{*}$ & $52588,60^{*}$ & 0,28 ns \\
\hline$S \times B$ interaction & 4 & 2,80 ns & $0,02^{\text {ns }}$ & $33,40 * *$ & $77,80 *$ & $45575,27^{* *}$ & $1,03^{* *}$ \\
\hline Residue & 30 & 8,27 & 0,07 & 3,81 & 13,15 & 3321,87 & 0,97 \\
\hline Overall mean & - & 13,29 & 2,00 & 10,60 & 20,25 & 230,47 & 1,36 \\
\hline $\mathrm{CV}$ & - & 21,65 & 14,13 & 18,43 & 17,91 & 25,01 & 22,77 \\
\hline
\end{tabular}

$\mathrm{CV}$ : coefficient of variation; DF: degree of freedom *,** significant at 5 and at $1 \%$, respectively, and ${ }^{\mathrm{ns}}$ not significant, by F test.
F
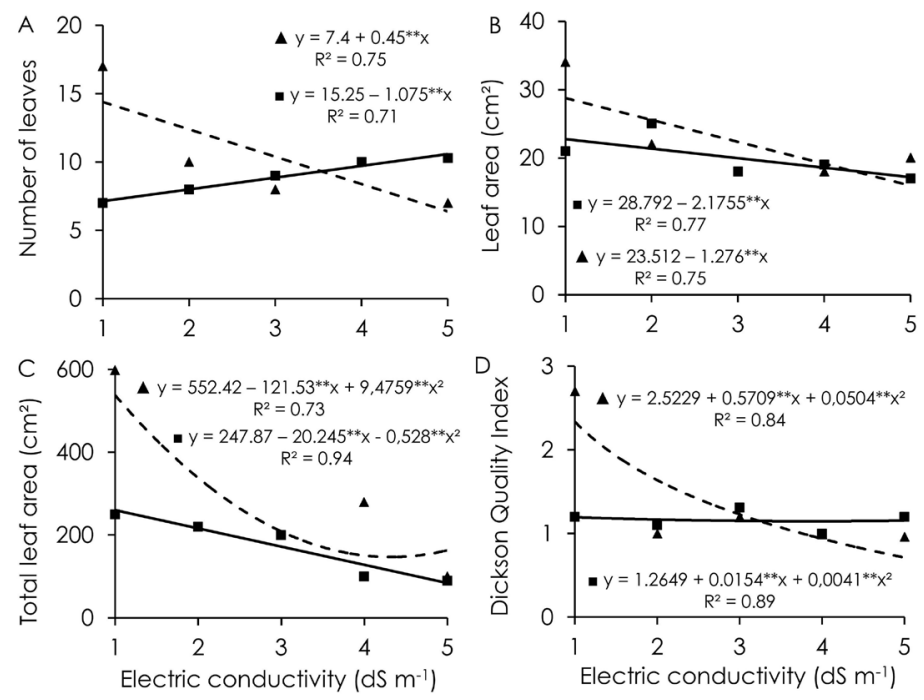

Figure 1: Number of leaves (A), leaf area (B), total leaf area (C) and Dickson quality index (D) of pitombeira seedlings irrigated with saline water with ( $\mathbf{\Lambda}$ ) or without ( $-\mathbf{l}$ ) bovine biofertilizer.

Similar results were observed in guava seedlings (Cavalcante et al., 2005) and yellow passion fruit (Costa et al., 2005) in which the number of leaves decreased with water salinity increase.

Rebequi et al. (2009) and Mesquita et al. (2012) during the formation of rangpur lime and yellow passion fruit seedlings under irrigation with saline water showed that the smallest decreases in number of leaves were observed in plants treated with biofertilizer. Some studies have shown that the application of biofertilizer possibly mitigates the effects of salinity on plant growth (Bezerra et al., 2010).

It can be observed for leaf area (Figure 1B), in both biofertilizer application conditions, that pitombeira seedlings presented significance, so that the best results were obtained with irrigation without addition of $\mathrm{NaCl}\left(0.8 \mathrm{dS} \mathrm{m}^{-1}\right)$ corresponding to the maximum value of 33.41 $\mathrm{cm}^{2}$ with the application of biofertilizer, while the

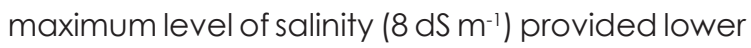
results of $14.14 \mathrm{~cm}_{\text {plant }}{ }^{-1}$ without the application of biofertilizer.

Similarly, Rebequi et al. (2009) studying rangpur lime seedlings under irrigation with saline water, observed smaller decreases of leaf area in plants treated with bovine biofertilizer. The bovine biofertilizer attenuates the effect of saline stress, due to the release of humic substances contained in the organic input, as a consequence, reduces the salinity effects of 
plants. The bovine biofertilizer attenuates the effect of saline stress due to the release of humic substances contained in the organic input, and as a consequence, reduces the salinity effects in plants (Brahmaprakash e Sahu 2012).

In irrigation conditions with high salinity water, the total leaf area reduced even in the presence of bovine biofertilizer (Figure 1C), obtaining mean of $64.44 \mathrm{~cm}$ without biofertilizer application at the maximum salinity level (8 dS $\mathrm{m}^{-1}$ ). Plants treated with biofertilizer presented superior results under salinity conditions. It was observed that pitombeira seedlings showed an increase at the level of $6 \mathrm{dS} \mathrm{m}^{-1}$, obtaining mean of $273.67 \mathrm{~cm}$ plant $^{-1}$ in the treatment with biofertilizer application.

The increase in salinity levels negatively influenced Dickson Quality Index in pitombeira seedlings without the application of biofertilizer.
As the salinity levels in the substrate increased, there was an expressive reduction in seedlings quality. In the treatments with biofertilizer, a small increase in Dickson quality index was verified as a function of salinity levels (Figure 1D).

Mesquita et al. (2015), working with neem seedlings (Azadirachta indica), Neto et al. (2014) evaluating oiticia seedlings also observed that high salinity levels decrease Dickson quality index.

Salinity levels, the application of bovine biofertilizer and the interaction of these factors influenced all variables (Table 3).

Seedlings irrigated with low salinity water presented a higher growth in root dry matter (Figure 5) when compared to those irrigated with high salinity water, even with the application of bovine biofertilizer.

Table 3: Summary of analyzes of variance for root dry mass (RDM), stem dry mass (SDM), leaf dry mass (LDM) and whole plant dry mass (WPDM) of pitombeira seedlings (Talisia esculenta A. St.-Hil.) Radlk.) cultivated under levels of electrical conductivity with or without bovine biofertilizer.

\begin{tabular}{|c|c|c|c|c|c|}
\hline \multirow[t]{3}{*}{ Source of variation } & $\mathrm{DF}$ & & Mean & Square & \\
\hline & \multicolumn{5}{|c|}{ Dry matter mass } \\
\hline & & RDM & SDM & LDM & WPDM \\
\hline Salinity levels & 4 & $2,50 * *$ & $4,00^{* *}$ & $15,25^{* *}$ & $56,83^{* *}$ \\
\hline Linear Regression & 1 & $5,00^{\mathrm{ns}}$ & $12,80^{* *}$ & $42,05^{* *}$ & $135,20^{* *}$ \\
\hline Quadratic Regression & 1 & $3,57^{* *}$ & $0,00^{n s}$ & $8,03^{* *}$ & 34,32 ns \\
\hline Regression deviation & 2 & 0,71 & 1,60 & 5,45 & 4,23 \\
\hline Biofertilizer & 1 & $2,50 * *$ & $1,60 * *$ & $13,22^{* *}$ & $16,90^{* *}$ \\
\hline$S \times B$ interaction & 4 & $2,50 * *$ & $1,60 * *$ & $11,85^{* *}$ & $66,46 * *$ \\
\hline Residue & 30 & 0,03 & 0,06 & 0,12 & 4,23 \\
\hline Overall Mean & - & 2,25 & 2,00 & 2,37 & 13,65 \\
\hline CV & - & 8,11 & 12,91 & 14,89 & 15,07 \\
\hline
\end{tabular}

Analyzing root dry matter mass under salinity levels for biofertilizer application, it was verified that under low salinity conditions, seedlings obtained a root dry matter mass with a maximum value of $5.5 \mathrm{~g}$ per plant, when irrigated with water of $0.8 \mathrm{dS} \mathrm{m}^{-1}$. Under high salinity water $\left(8 \mathrm{dS} \mathrm{m}^{-1}\right)$ there was an average of $2 \mathrm{~g}$ per plant with biofertilizer application.

Similar results were obtained by Costa et al. (2005) inyellow passion fruit and Rebequi et al. (2009) in rangpur lime, who observed that irrigation with saline waters reduced the root dry mass of these crops. Medeiros et al. (2011) also found that biofertilizer application provided the best results for root dry mass.
Irrigation with high salinity water considerably reduced stem dry mass in pitombeira seedlings. However, when the seedlings were treated with biofertilizer there was a mitigating effect (Figure 2B).

Lima Neto et al. (2015), studying tamarind seedlings, verified that root, stem and leaf dry mass were negatively affected by water salinity levels. However, there was a smaller reduction of stem dry mass in the seedlings treated with biofertilizer.

Irrigation with high salinity water (8 $\mathrm{dS} \mathrm{m}^{-1}$ ) resulted in a decrease in leaf dry mass of pitombeira corresponding to $1.25 \mathrm{~g} \mathrm{plant}^{-1}$ in the seedlings treated with bovine biofertilizer under irrigation 
with low salinity water $\left(0.8 \mathrm{dS} \mathrm{m}^{-1}\right)$. Higher results were found with mean of $7.5 \mathrm{~g}$ per plant (Figure $2 \mathrm{C})$. The reduction of leaf dry mass as a function of salt stress was also reported by Cavalcanti et al. (2005). This result can be explained by the fact that biofertilizer mitigates the effects of saline stress, as a result of the humic substances release.

A decreasing quadratic polynomial response to the interaction of salinity levels with the biofertilizer can be observed for the whole plant dry mass (Figure 2D), in both biofertilizer application condition. Pitombeira seedlings presented statistical difference, so that the best results were obtained with irrigation without addition of $\mathrm{NaCl}\left(0.8 \mathrm{dS} \mathrm{m}^{-1}\right)$, obtaining the maximum value of $24 \mathrm{~g}$ per plant with the application of biofertilizer, while the maximum level of salinity $\left(8 \mathrm{dS} \mathrm{m}^{-1}\right)$ provided lower results
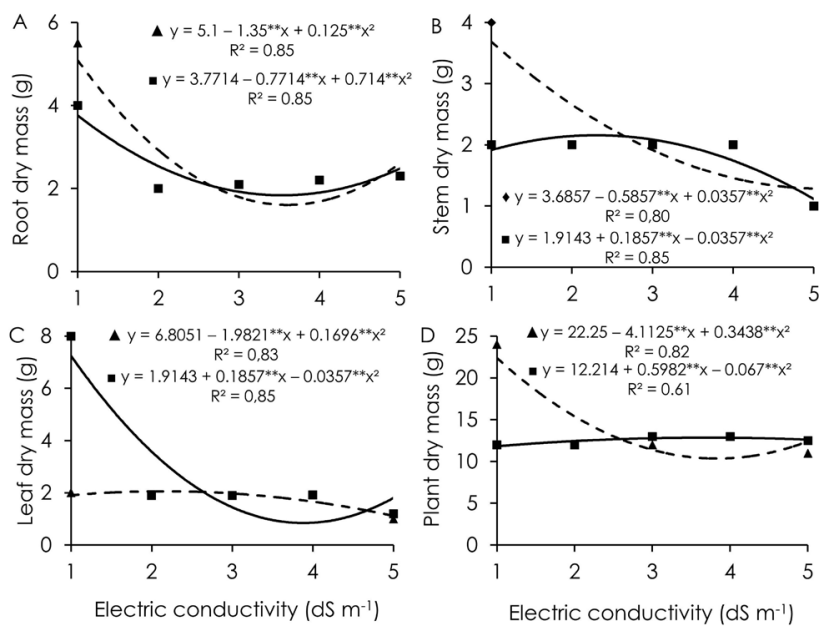

Figure 2: Root dry mass (A), stem dry mass (B), leaf dry mass (C) and whole plant dry mass (D) of pitombeira seedlings irrigated with saline water with () or without (-) bovine biofertilizer.

\section{References}

Alves, E. U., Monte, D. M. O., Cardoso, E. A., SantosMoura, S. S., Moura, M. F. 2013. Emergência e crescimento inicial de Talisia esculenta (A. St. -Hill) Raldk em função de profundidades e posições de semeadura. Bioscience Journal 29: 328-339.

Alves, G. S., Santos, D., Silva, J. A., Nascimento, J. A. M., Cavalcante, L. F., Dantas, T. A. G. 2009. Estado nutricional do pimentão cultivado em solo tratado com diferentes tipos de biofertilizantes. Acta Scientiarum Agronomy 31: 661-665.

Araújo, E. N., de Oliveira, A. P., Cavalcante, L. F., Pereira, W. E., de Brito, N. M., Cynthia, M. D. L., Silva, É. É. da. 2007. Produção do pimentão adubado com esterco bovino e biofertilizante.
(10.25 g plant) under biofertilizer application.

Other fruit trees showed this behavior, as observed by Sousa et al. (2011) in cashew tree, Cavalcante et al. (2010) in guava, Silva and Amorim (2009) in umbuzeiro and Sá et al. (2013) in papaya tree. Mesquita et al. (2010) studying the production of yellow passion fruit seedlings in substrate with bovine biofertilizer irrigated with saline waters observed that the whole plant dry mass was negatively affected by the saline increment. However, in the soil with bovine biofertilizer, there was less influence.

\section{Conclusions}

The increase in salinity decreases growth and dry matter of pitombeira seedlings. The use of biofertilizer mitigates the harmful effects of salinity on pitombeira seedlings. 
Cavalcante, L. F., Cavalcante, Í. H., Pereira, K. S., Oliveira, F. A. D., Gondim, S. C., de Araújo, F. A. 2005. Germination and initial growth of guava plants irrigated with saline water. Revista Brasileira de Engenharia Agrícola e Ambiental 9: 515-519.

Cavalcante, L. F., Vieira, M. S., Santos, A. F., Oliveira, W. M., Nascimento, J. A. M. 2010. Água salina e esterco bovino líquido na formação de mudas de goiabeira cultivar Paluma. Revista Brasileira de Fruticultura 32: 251-261.

Costa, E. G., Carneiro, P. T., Soares, F. A., Fernandes, P. D., Gheyi, H. R., Cavalcante, L. F. 2005. Crescimento inicial do maracujazeiro amarelo sob diferentes tipos e níveis de salinidade da água de irrigação. Revista Brasileira de Engenharia Agrícola e Ambiental 9: 242-247.

Dickson, A., Lead, A. L., Osmer, J. F. 1960. Quality appraisal of white spruce and white pine seedling stock in nurseries. Forestry chronicle 36: 0-13.

Ferreira, D. F. 2007. Sisvar Versão 5.0. UFLA: Lavras, Brasil.

Lacerda, C. F. Interação salinidade x nutrição mineral. In: Nogueira, R. J. C., Araújo, E. L., Willadino, L. G., Cavalcante, U. M. T. (eds.) 2005. Estresses ambientais: Danos e benefícios em plantas. Recife, PE, Imprensa Universitária, 95-105.

Medeiros, R. F., Cavalcante, L. F., Mesquita, F. O., Rodrigues, R. M., Sousa, G. G., Diniz, A. A. 2011. Crescimento inicial do tomateiro-cereja sob irrigação com águas salinas em solo com biofertilizantes bovino. Revista Brasileira de Engenharia Agrícola e Ambiental 15: 505-511.

Mesquita, F. D. O., Rebequi, A. M., Cavalcante, L. F., Souto, A. G. D. L. 2012. Crescimento absoluto e relativo de mudas de maracujazeiro sob biofertilizante e águas salinas. Revista de Ciências Agrárias 35: 222-239.

Mesquita, F. O., Nunes, J. C., Lima Neto, A. J. de, Luna Souto, A. G. de, Batista, R. O., Cavalcante, L. F. 2015. Formação de mudas de nim sob a salinidade, biofertilizante e drenagem do solo. Irriga 20: 193-203.

Mesquita, F. de O., Cavalcante, L. F., Pereira, W. E., Lima Neto, A. J. de, Nunes, J. C. 2012. Produção de mudas de maracujazeiro amarelo submetidas à salinidade em solo como biofertilizante bovino. Ciencia del suelo 30: 31-41.

Neto, M. A. D., Silva, I. D. F. da, Cavalcante, L. F., Diniz, B. L., Silva, J. C. da, Silva, E. C. da. 2014. Mudas de oiticica irrigadas com águas salinas no solo com biofertilizante bovino e potássio. Revista Brasileira de Engenharia Agrícola e Ambiental 18: 10-18.
Nunes, J. C., Cavalcante, L. F., Rebequi, A. M., Lima Neto, A., Diniz, A. A., Silva, J. J. M., Brehm, M. D. S. 2009. Formação de mudas de noni sob irrigação com águas salinas e biofertilizante bovino no solo. Engenharia Ambiental 6: 451-463.

Rebequi, A. M., Cavalcante, L. F., Nunes, J. C., Diniz, A. A., Brehm, M. A. D. S., BeckmannCavalcante, M. Z. 2009. Produção de mudas de limão cravo em substrato com biofertilizante bovino irrigado com águas salinas. Revista de Ciências Agrárias 32: 219-228.

Rhoades, J. D., Kandiah, A., Mashali, A. M. Uso de águas salinas para produção agrícola. 2000. UFPB: Campina Grande - PB, Brasil, 117p.

Richards, L. A. Diagnosis and improvement of saline and alkali soils. Washington: US Department of Agriculture, 1954. 160p. USDA Agricultural Handbook, 60.

Sá, F. V. D. S., Pereira, F. H., Lacerda, F. H., Silva, A. B. da. 2013. Crescimento inicial e acúmulo de massa seca de cultivares de mamoeiro submetidas à salinidade da água em cultivo hidropônico. Revista Brasileira de Ciências Agrárias 8: 435-440.

Silva, M. G., Amorim, S. M. C. 2009. Estresse salino em plantas de Spondias Tuberosa Arruda (Câmara) colonizada com fungos micorrízicos arbusculares. Revista Caatinga 22: p.91-96.

Soares, F. A. L., Gheyi, H. R., Viana, S. B. A., Uyeda, C. A., Fernandes, P. D. 2002. Water salinity and initial development of yellow passion fruit. Scientia Agricola 59: 491-497.

Sousa, A. D., Bezerra, M. A., Farias, F. C. 2011. Germinação e desenvolvimento inicial de clones de cajueiro comum sob irrigação com água salina. Revista Brasileira de Engenharia Agrícola e Ambiental 15: 390-394.

Sousa, G. B., Cavalcante, L. F., Cavalcante, Í. H. L., Beckmann-Cavalcante, M. Z., Nascimento, J. A. 2008. Salinidade do substrato com biofertilizante para formação de mudas de maracujazeiro irrigado com água salina. Revista Caatinga 21: 172-180.

Távora, F. J. A. F., Pereira, R. G., Hernandez, F. F. F. 2001. Crescimento e relações hídricas em plantas de goiabeira submetidas a estresse salino com $\mathrm{NaCl}$. Revista Brasileira de Fruticultura 23: 441-446. 